\title{
The Efficacy of Picture and Music on Pre-writing Stage of Iranian EFL University Students
}

\author{
Zahra Rostami Sarabi, Arezoo Ashoori Tootkaboni \\ Shahid Beheshti University
}

\begin{abstract}
Many language learners experience difficulties in eliciting ideas in L2 writing. However, this issue has been given scant attention in EFL context due to its complexity. It is altogether crystal clear that Iranian student-writers suffer from incapability in expressing themselves in English. The present study addresses the effectiveness of picture, music, and topic tools in facilitating ideas in pre-writing stage. In other words, the pivotal question of this study is as follows: How do EFL university students react toward pictorial, musical, and topical writing environments in pre-writing stage? Consequently, this study was undertaken to examine the effectiveness of generating ideas through pictorial, musical, and topical methods. To that end, 61 university sophomore students majoring in English language translation participated in this study. Writing assignment included picture-guided, topicselected, and music- guided. Results of the study demonstrated that the employment of music as a guided writing environment was a spring boards for EFL learners to jumpstart their writing with more expanded ideas. Moreover, students in music experimental group could expand their imagination to express themselves better in the target language. In other words, the result of this quasi-experimental study revealed that both treatment groups outperformed the control group on the writing posttests; it was also shown that the differences between the two treatment groups on this measure were statistically significant. It can be claimed that music served as a facilitative aid in generating ideas in the prewriting stage. Generally speaking, findings suggest that foreign language teachers should be encouraged to use the musical approach for L2 writing courses.
\end{abstract}

\section{Introduction}

As language teachers, we find out that writing has been the most difficult part for language learners to develop [28], especially because it requires the production of the language. Over the past few decades of research on teaching writing to EFL learners, a number of issues have appeared, some of which remain controversial in spite of reams of data on language witting. Unlocking the hidden ideas in learners' minds is one of the thorniest issues in this regard. The majority of language learners experience difficulties in eliciting ideas in L2 writing called "writer's cramp" (mental block) (Brown, [5]). Facing such a circumstance, they beat their head against the brick wall of trying to come up with an interesting idea to grow and cook a message. Thus, it is essential for language teachers to provide a stimulating tool to inspire students to write. In other words, among the stages L2 learners undergo in writing, starting to write is the most frequent problem encountered (Hedge [17]). Unfortunately, most students do not take the time to organize their train of thoughts when asked to write about a topic. They are sort of being exposed to "tunnel vision" they can't see the forest for the trees; they are over occupied by handing in polished piece of writing. Several techniques have been introduced, among them free writing, clustering, and brainstorming are frequently used. As language teachers, we realize that most of our learners are interested in music and pictures. Despite the pervasiveness of music and pictures in our life, EFL language teachers do not yet make use of them as powerful vehicles to motivate learners to write. Language learners need to imagine. Their imaginative abilities must be cultivated through more creative techniques such as picture, music, film, etc.... Increasingly the arts and imaginative experiences have been marginalized to the edges rather than placed at the center of the writing curriculum especially in EFL context. However, little empirical research has been conducted to lend credence to pre-writing stage. In order to bridge the gap, we conducted present study to explore the potential effectiveness of topicselected, picture-guided, and music-guided environments in generating ideas in pre-writing stage. The present study addresses the following research questions:

1. What is the effect of music-guided environment in pre-writing stage of EFL university students?

2. What is the effect of picture-guided environment in pre-writing stage of EFL university students?

3. Is one technique music or picture more facilitative and effective than the traditional method of topic-selected environment? 


\section{Review of related literature}

How is writing the same as swimming? The psychologist Eric Lenneberg once noted, in a discussion of "species specific" human behavior, that human beings universally learn to walk and to talk, but that swimming and writing are culturally specific. Instruction in English as a Second Language (ESL) has often focused on improving students' skills and abilities in speaking, listening, and reading in the target language (L2) while ignoring the development of the students' writing skills. Harris [16] concluded that only $2 \%$ of ESL instruction was concerned with writing activities. Of this two percent, $72 \%$ was related to the mechanical aspects of writing such as syntax, punctuation, and spelling. Yet for L2 learners, writing is an essential language reinforcing skill. Therefore, it is obvious that generating ideas in pre-writing stage is overlooked by the majority of language teachers. Littlewood [21] claims that writing is the art of "conceptualizing our message with the maximum possible accuracy and clarity”, which makes writing more complex. In addition, being "recursive in nature" (Cohen [6]), writing requires learners to undergo several stages, which might "appear more than once and in different sequences" such as prewriting, drafting, revising and editing (Proett and Hammond [15]).

Another common problem is that learners might have stumbling blocks in deciding what to write, even after they get the ideas, they still need more time to organize their thoughts into a systematic pattern. Unfortunately, in the classroom practice, no one can wait around for several weeks while ideas for writing slowly come to fruition (Harris [16]).

The most obvious problem often encountered by L2 learners is difficulties in eliciting ideas, as pointed out by Hedge [17]. A research conducted in Indonesia showed 7 students out of 12 who were interviewed claimed that they had no idea when the teacher asked them to do in-class writing. Unfortunately, brilliant ideas might not come at the right time; they can come before you sleep or when you eat. What is a worse, good idea can get away if they are not written down (Cohen, [6]). Final possible problem is the "lack of explicitness" when expressing the idea. Sometimes learners are not able to express clearly what they want to say. Ideas go unchallenged in writing, since audience's reaction usually comes after the writing is done.

Ackerman [1] postulated that professional writers use pre-writing techniques in creating their works. For example, the French journalist and writer, Blazac, drank more than fifty cups of coffee each day to help the ideas begin to flow. We rarely ask our students to do the same or even similar activity as a pre-cursor to their writing. As Dörnyei suggests, "the cohesiveness-performance effect can be particularly strong in language classes in which the learners communicative skills are developed primarily through participatory experience in real world tasks" [9]. Pre-writing allows students to participate in this real world task of the writing process. Rau and Sebrechts found that it was not enough for students to see the ideas just on paper. Rather, they discovered that using pre-writing activities led to more changes to text content and less to syntax, and that the resulting compositions were judged to be more sophisticated and creative, regardless of the writing medium. The present study is a seed bed to shift writing evaluation to more meaning-based orientation rather than obsession with grammatical structures. It is also a stepping stone for language practitioners and educators to employ more creative techniques in their classroom in order to change the stifle atmosphere of the classroom especially in advanced and tertiary levels.

\section{The role of picture in pre-writing stage}

Pictures or drawings have been widely utilized to facilitate the teaching process and to enhance learning outcomes. Pictures often are used as a visual stimulus to attract learners' attention, to increases their motivation as well as to assist them in development of analytical thinking skill. Pictures provide contextual cues that allow viewers to interpret, to organize and even to create ideas behind the context (Bransford \& Johnson [2]).Furthermore, pictures can be manipulated in various avenues to boost L2 writing process from the novice to the advanced level. A body of research has shown that pictorial materials for L2 learning have proved the positive effect on listening, speaking, and especially reading skills. Accordingly, pictures as a "guided" writing environment not only facilitate learning of vocabulary and grammatical structures, but also evoke learners' cognitive skills to organize, compose and express ideas for communicative purposes. As writing in L2 is stressful and anxiety-provocative, the pictorial instruction can provide learners a friendly atmosphere for writing in the target language. Photo elicitation was first named in a paper published by the photographer and researcher John Collier [7], who was, in the mid-1950s, a member of Cornell University's multi-disciplinary research team examining mental health in changing communities in the Maritime Provinces in Canada. Collier proposed photo interviewing as the solution to a practical problem.

Unlike many research methods, photo elicitation works (or does not) for rather mysterious reasons. But at the other extreme many researchers believe that photo elicitation mines deeper shafts into a different part of human consciousness than do words-alone performance. It is partly due to how remembering is enlarged by pictures and partly due 
to the particular quality of the pictures itself. Photographs appear to capture the impossible: a person gone; an event past. That extraordinary sense of seeming to retrieve something that has disappeared belongs alone to the photograph, and it leads to deep and interesting talk.

\section{The role of music in pre-writing stage}

Music is consisted of elements such as melody, harmony, timbre, rhythm, tempo, and lyrics. According to Torres and Torres, those elements are related to each other in creating both harmonic and disharmonic music. All elements of music can be exploited to elicit ideas in writing. For example, the context, lyrics and rhythm provided in the song can stimulate learners' imagination. Griffee [14] states that the elements of music can help creating friendly and cooperative atmosphere that is significant in language learning. A large number of research studies have been carried out on the impacts of music in the second language classrooms. In the area of reading and writing, DiEdwardo conducted a research study in order to answer the question whether music in the language classroom setting can improve students' reading and writing skills. Statistical results of case study research have suggested that pairing music and linguistic intelligences in the college classroom improves students' grades and abilities to compose these statements for research papers in courses that emphasize reading and writing skills.

The use of music in the second language classroom can also affect learners' motivation in learning. According to a research study conducted by Weisskoff (1981), students who received the medium of commercially-recorded pop/rock music as an integral part of the instructional package in language arts scored significantly higher with regard to continuing motivation. In this research study, Weisskoff made comparisons between alternate learning conditions - using music and no music with respect to writing performance and continuing motivation. The study pointed out that, "students who were almost always unmotivated became motivated because of music" (ibid.). Music is known to bring psychological effects to its listeners. Most of the time, we feel happier when listening to joyful songs. We tap our fingers and feet unconsciously following the rhythm of the music. Sometimes our favorite music can help us recall our memory about certain moments. In the area of writing, Wijaya (2006) conducted a study to find out whether music influences L2 learners in writing. The findings indicated the positive effects of music in enhancing L2 writing . Nearly all the respondents confirmed that the use of music in their writing classrooms helped them in writing. They felt that listening to music while writing could make them relaxed and calm so that their ideas could flow easily. This supports Cross' [8] and Brewer's [3] ideas that music can create a relaxed environment. Moreover, the music could make the learners focus more on what they wrote.

Murphey [24] also says that "music has the potential to change the atmosphere", but what is more important than his confirmation of this fact is that in this case he means the atmosphere in a classroom, and describes music as follows: "It seems to give energy where was none, and to spark off images when students complain of having nothing to write about. "Music is the stuff dreams grow on.", (p.37). There are several justifications of using music to stimulate learners in L2 writing. First, music is universal. Everyone - adult, children, teenagers, and old people - likes music. Moreover, it can cater to different level of learners (Murphey [24]). Second, music is everywhere. It is hard to escape music and songs as they occupy more of the world around us. You listen to it when you go to restaurants, malls, or when you turn on your radio when you drive your car etc (ibid.). Some music can also be accessed for free, for example from the Internet where you can download or listen to. Third, music is relaxing. A wide range of research has indicated the significant effects music can bring to our brain. It has been used in the medical field as a sort of therapy for Music has been used as therapy to stabilize blood pressure, mental illness, depression, stress, insomnia and premature infants. Julius Portnoy found that music has powerful effects on our digestion and energy system. In a classroom context, music can provide variety and fun, and encourage harmony within oneself and a group. Music creates a happy and relaxed environment (Cross [8]; Brewer, [3]). Music is also used as a means of lowering anxiety and diminishing tension, and inducing the state of relaxed alertness considered optimal for second language acquisition (Krashen [18]). Finally, music can help people to build vocabulary. The repetition used in the song's lyrics can help learners remember vocabulary easily (Griffee [14]). In addition, it is much easier to learn vocabulary in the context of the songs. Music is used in a meaningful context (Dakin, 1968: 14). In general, lyrics in songs have theme lines, or story behind which makes learners can learn language in a meaningful context. "Also, songs offer rich background and social and historical context to language learning” [14]. "Songs can evoke historical period e.g. Christmas songs in Christmas season" (ibid. 5).

\section{Methodology}

As has been mentioned in the abstract of the study, the main aim of this study is to inject a healthy dose of music and picture into EFL writing context. 
To fulfill such a purpose, a quasi-experimental study was designed to answer the research questions.

\section{Participants and instructional setting}

This study was conducted during fall semester 2011 at Tonekabon Open University in Iran. The sample group involved 61 sophomore students majoring in English language translation with average year of 22.5 years old both male and female. They have passed two courses in basic writing. In order to keep the proficiency level of the participants almost on the same par, the researchers administered a writing pretest to all students. Comparison of mean difference among three groups showed no significant difference among them. The researchers also crossed five students' results out of the data due to very high and very low writing proficiency as the outliers of the study.

\section{Materials}

At the outset of the study, one of the researchers, the lecturer of the course, administered the writing pre-test to all 61 students to ensure their homogeneity in writing proficiency. She selected two topics randomly out of ten including descriptive and cause- effect. After nine sessions of treatment, she administered writing post-test. In a similar vein, students were required to write two essays about two topics selected randomly. The researcher tried to prompt ideas in one of the experimental groups through showing pictures. She also elicits ideas in the other experimental group through playing pop songs. The researchers did their hardest to search on the internet to find songs with series of pictures in accordance with each other as the writing prompts.

\section{Procedure}

This study required 61 homogenous EFL university students who have passed two basic witting courses. First, the researcher randomly assigned the classes into two experimental and one control group. Then, the researchers administered the writing pre-test to all the participants to prove students' homogeneity in writing. She asked students to write about two topics chosen randomly; descriptive and cause-effect. Prior to the first writing, students were advised to write for message and communication but not for error-free polished piece of writing. According to Dvorak [11], the evaluation of students writing should be focused on the effectiveness of content rather the accuracy of grammatical structures. In addition, a sheet of handout for tips for writing strategies was presented to all participants. For each topic, all students were allowed to write for 30 minutes and use dictionary.
To evaluate their writing proficiency, the two researchers rate the writing based on the criteria mentioned in a new writing rating scale of Sasaki). In this scale, elements of clarity of theme, expressions, and organization were taken into consideration. Moreover, scoring of the test was a little changed by the researchers. Therefore, a conclusion could be drawn that all students were at the same level of writing proficiency.

Students in the music group were given musical prompts as pre-writing in that each session they were assigned to listen to a pop song while brainstorming their ideas. Then they were provided with lyrics of the songs. Finally they were asked to write different kinds of essays based on the songs. In the pictorial class, the lecturer showed them some pictures corresponded to the song of each session asking students to write an essay. It should be clarified that students in the control group were assigned to topics to write their essays. Moreover, all participants in all three classes were assigned to the same writing content through different instruction of music, picture, and topic. Specific grammatical structures and vocabulary were required for each writing assignment. To put it into perspective, students in the music class listen for instance to one of Michael Jackson's songs "Earth" while they were brainstorming, then they were asked to write a causeand-effect essay about earth revolution and global warming. In a similar vein, students in the picture class were given a series of picture regarding global warming, deforestation, and air pollution. After brainstorming their ideas they were asked to write a cause-and-effect essay about earth revolution and global warming. Incidentally, students in the control class were given the topic of "earth revolution and global warming" to write a cause-and-effect essay. The treatment lasted for nine sessions a whole semester. After the treatment students were given two topics randomly out of ten topics (comparison and descriptive) to write.

For the evaluation of the essays, elements of clarity, expression, and organization were taken into consideration using a standard writing scale Adapted from Miyuki Sasaki [27]. All 61 essays were marked by two raters, two colleagues. Inter-rater reliability was computed by Pearson-product Moment Formula. The inter-rater reliability was: (Music-guided group $=87.42$ ), (Picture-guided group $=91.22$ ), and (Control group $=88.34)$. These results indicated that scoring of all three groups were highly reliable.

\section{Results}

To examine the effectiveness of different techniques of idea elicitation in pre-writing stage, the results of the pre and posttests were calculated in a quantitative manner. To guarantee the homogeneity of three groups at the begging of the study, writing 
pre-test was administered and the scores were put into a one way ANOVA. Furthermore, to assess the impact of different techniques on pre-writing stage, again one way ANOVA was used.

Table 1: Descriptive Statistics: Results of the pretest among three groups.

\begin{tabular}{|l|l|l|l|}
\hline Groups & Number & Mean & $\begin{array}{l}\text { Standard } \\
\text { deviation }\end{array}$ \\
\hline Music & 22 & 10.55 & 2.041 \\
\hline Picture & 21 & 11.14 & 2.435 \\
\hline $\begin{array}{l}\text { Control } \\
\text { group }\end{array}$ & 18 & 10.44 & 2.148 \\
\hline
\end{tabular}

The results presented in Table 1 revealed that the mean scores among the three groups are quite similar (Music: 10.55, picture: 11.14, Control Group: 10.44). Other statistics set out in Table 2 further showed that there is no subject difference among the three groups $(\mathrm{F}=.590, \mathrm{p}=.557>0.05)$. Thus, it a conclusion could be drawn that all the three groups were at the same point of writing proficiency.

Table 2:One-way ANOVA: Results of the pre-test scores among three groups.

\begin{tabular}{|l|l|l|l|l|l|}
\hline & $\begin{array}{l}\text { Sum of } \\
\text { Scores }\end{array}$ & df & $\begin{array}{l}\text { Mean } \\
\text { Squares }\end{array}$ & F & Sig. \\
\hline $\begin{array}{l}\text { Between } \\
\text { Groups }\end{array}$ & 5.792 & 2 & 2.896 & .590 & .557 \\
\hline $\begin{array}{l}\text { Within } \\
\text { Groups }\end{array}$ & 284.47 & 58 & 4.905 & & \\
\hline Total & 290.262 & 60 & & & \\
\hline
\end{tabular}

Comparison of writing posttest: Table 3 represents the means of writing scores as the posttest: it is crystal clear that, means of music group (17.32) is higher than of the other two groups.

Table 3: Descriptive statistics: Results of writing post-test among three groups

\begin{tabular}{|l|l|l|l|}
\hline Groups & Number & Mean & SD \\
\hline Music & 22 & 17.32 & 1.393 \\
\hline Picture & 21 & 15.19 & 2.089 \\
\hline Control & 18 & 11.28 & 2.109 \\
\hline Total & 61 & 14.80 & .395 \\
\hline
\end{tabular}

To figure out about the significance of these differences, a One-way ANOVA was run. The results are presented in table 4.

Table 4:One-way ANOVA: Results of the writing post-test scores among three groups.

\begin{tabular}{|l|l|l|l|l|l|}
\hline & $\begin{array}{l}\text { Sum of } \\
\text { Scores }\end{array}$ & df & $\begin{array}{l}\text { Mean } \\
\text { Squares }\end{array}$ & F & Sig. \\
\hline $\begin{array}{l}\text { Between } \\
\text { Groups }\end{array}$ & 366.017 & 2 & 183.009 & 52.128 & .000 \\
\hline $\begin{array}{l}\text { Within } \\
\text { Groups }\end{array}$ & 203.622 & 58 & 3.511 & & \\
\hline
\end{tabular}

\begin{tabular}{|l|l|l|l|l|l|}
\hline Total & 569.639 & 60 & & & \\
\hline
\end{tabular}

It can .05 concluded from the above table that there is a significant difference among the groups concerning the idea elicitation techniques in the writing posttest, $\mathrm{F}(52.128), \mathrm{p}=.00<.05$. To place the exact point of difference, a Sheffe test was run whose results are presented in table 5 .

Table 5: Scheffe test of differences across the groups on the writing post-test.

\begin{tabular}{|c|c|c|c|}
\hline $\begin{array}{l}\text { (I) grouping }(\mathrm{J}) \\
\text { grouping }\end{array}$ & $\begin{array}{l}\text { Mean } \\
\text { difference } \\
(\mathrm{I}-\mathrm{J})\end{array}$ & Std. Error & Sig. \\
\hline $\begin{array}{lr}\text { Music } & \text { Picture } \\
& \text { Control }\end{array}$ & $\begin{array}{l}2.128 * \\
6.040^{*}\end{array}$ & $\begin{array}{l}.572 \\
.595\end{array}$ & $\begin{array}{l}.002 \\
.000\end{array}$ \\
\hline $\begin{array}{rr}\text { Picture } \begin{array}{c}\text { Music } \\
\text { Control }\end{array} \\
\end{array}$ & $\begin{array}{l}-2.128^{*} \\
3.913^{*}\end{array}$ & $\begin{array}{l}.572 \\
.602\end{array}$ & $\begin{array}{l}.002 \\
.000\end{array}$ \\
\hline $\begin{array}{r}\text { Control Music } \\
\text { Picture }\end{array}$ & $\begin{array}{l}-6.040 \\
-3.913 \\
\end{array}$ & $\begin{array}{l}.595 \\
.602\end{array}$ & $\begin{array}{l}.000 \\
.000\end{array}$ \\
\hline
\end{tabular}

*The mean difference is significant $t$ the 0.05 level.

As can be seen, the one-way ANOVA revealed that there is a significant difference among all groups. To put it into perspective, the students in music group outperformed the other two groups. In a similar vein, students in the picture group scored higher than the control group, thus it can be concluded that students in picture idea elicitation performed better than the control group; i.e. topicselected group

\section{Discussion}

A guiding theme of this paper was to show the efficacy of music and picture for boosting prewriting stage of a group of Iranian EFL university students. Using a quasi-experimental design, the results obtained revealed that the music group made a significant gain over the other two groups. They outperformed in the results of writing posttest regarding content, coherence, and organization of the essays. In other words, students who listened to the songs as idea generators had a significantly higher gain over students who were shown pictures as the writing prompts. Moreover, results indicated that picture group outperformed the topic-selected group in the writing post-test. Thus, it showed that picture group was more successful at breaking their mental block. The bottom line is musicality of writing prompts in pre-writing stage of EFL context becomes not an option, but a stepping stone in effectiveness. As a natural consequence, then, the employment of music with the context of EFL context offers significant advantages to language learners. It serves as a means of reducing stress and affective barriers. 
The result of this study is in tune with Wijaya who stated the positive effects of music in enhancing L2 writing. His study showed that nearly all the respondents accepted that the use of music in their writing classrooms helped them in writing. They felt that listening to music while writing could make them relaxed and calm so that their ideas could flow easily. This supports Cross' [8] and Brewer's ideas [3] that music can create a relaxed environment. Moreover, the music could make the learners focus more on what they wrote. It is also confirmed with DiEdwardo who postulated that pairing music and linguistic intelligences in the college classroom improves students' grades and abilities to compose theses statements for research papers in courses that emphasize reading and writing skills.

Finally the results of this study is in line with Weisskoff, in his research study, Weisskoff made comparisons between alternate learning conditions using music and no music - with respect to writing performance and continuing motivation. The study pointed out that, "students who were almost always unmotivated became motivated because of music" (ibid.). Murphey [24] claimed that music is highly memorable, it also creates a state of relaxed receptivity, its rhythms correspond in some way with basic body rhythms, its messages touch deep-seated emotional or aesthetic chords, its repetitive patterning reinforces learning without loss of motivation, stuck in my head. The result also indicated that L2 writing was more fun and less stressful when students were asked to write their essays after listening to music. Interestingly, students felt that music kept them from being too obsessed with grammatical minutes, while they were concentrating on the content of songs. This assertion is consistent with one of the hypotheses of more efficient composing strategies in language learning. The hypothesis concerns the avoiding of focusing on "form" but instead on "meaning" as proposed by Krashen [19].

Generally speaking, there are different factors that might have led to the above mentioned results. Research has shown that during an electroencephalogram (EEG), music can change brain waves and make the brain more receptive to learning. Music connects the function of the right and left hemispheres of the brain so they can work together and make learning quick and easy. Brain function is increased when listening to music which leads to promoting more complex thinking. It can make connections between emotions, thinking, and learning. Suggestopedia was introduced by Lazanov which stress the significance of mental calmness in learning. Suggestopedia is a method of language teaching that capitalizes on relaxed states of mind for maximum retention of material. Music plays a vital role in this teaching method. For example, Baroque music with its 60 beats per minutes and its specific rhythm creates a kind of "relaxed concentration" for active learning.

\section{Conclusion}

The creative instruction of music employment in EFL context accelerated students' abilities in idea generation. Students in the music group felt their writing experience stress free; they also found the technique invaluable, absorbing, and helpful. However, a few students claimed that they did not receive much benefit from the musical instruction due to their learning styles. They preferred picture guided instruction because of their personal preferences toward pictures.

The punch line of this study revealed that imagination and thoughts can also be drawn out by listening to music. Music, for instance, can bring back powerful memories, learning experience and information, which might be buried in mind because of human's routines [3]. Music can also soothe our soul and this comforting mood adds the creativity in our imagination. This can help learners solve the problems in starting to write. Music can also facilitate learners to express their ideas and feelings in L2 writing. Background music can also be played during the writing process to stimulate internal processing, to smooth the progress of creativity, and promote personal reflection; and even one study revealed that learners wrote twice as much with music than without (ibid.). As the pedagogical implication of this study, language EFL practitioners and educators can enjoy the benefit form the result of this study in that they employ music especially pop songs in children level and tertiary level as well. They can shift the stifled atmosphere of the classroom to a friendly and stress less ethos. Furthermore, the result of this study make a seed bed for language teachers and text book writers to allot more quality time in pre-writing stage through different creative techniques.

Finally, the role of music in language classroom is truly multifaceted and thus requires experiments from different angles on different aspects. The result of this study underscore a dire need for more followup study using a large number of subjects in order to increase the external generalizability of the study in the same scope. Further research on the role of music on other language skills needed to be conducted.

\section{References}

[1] Ackerm, D. (1989).”You do make things difficult!” The New York Times Book Review.17(3), 1-3.

[2] Bransford, J. d., \& Johnson, M. K. (1972). “Contextual prerequisites for understanding: Some investigations of 
comprehension and recall,” Journal of Verbal Learning and Verbal Behavior 11(2), 717-726.

[3] Brewer, C. B. \& D. G. Campbell (1992). Rhythms of learning: Creative tools for developing lifelong learning (pp. 66-70). Tucson, AZ: Zephyr Press.

[4] Brown, H. D. (1987). Principles of language learning and teaching (2nd Ed) (pp.334-338). NJ: Englewood Cliffs, Prentice Hall.

[5] Brown, H. D. (1989). "Language program evaluation: A Synthesis of existing possibilities” (pp.44-80) .Second Language Curriculum. Cambridge University Press.

[6] Cohen, A. D., (1990). "Student processing of feedback on their compositions." In A. Wenden and J. Rubin, eds. Learner Strategies in Language Learning (PP.3-36). Englewood Cliffs, NJ: Prentice Hall.

[7] Collier, J. Jr.( 1957). "Photography in anthropology: a report on two experiments," American Anthropologist. 59(7), 843-859.

[8] Cross, D. (1995). A Practical Handbook of Language Teaching (pp.543-547).Hertfordshire: Phoenix ELT.

[9] Dörnyei, Z. (1997). "Psychological processes in learning cooperative language learning: Group dynamics and motivation”. The Modern Language Journal, 8(4), 482-493.

[10] Duchastel, P. C., \& Waller, R. (1979). "Pictorial illustrations in instructional texts.” Educational Technology, 29(11), 20-25.

[11] Dvorak, Trisha, (1986). "Writing in the Foreign Language”. In B. Wing (Eds). Listening, Reading, and Writing: Analysis and Application (pp.145-167). Oxford University Press.

[12] Eken, D. K. (1996). "Ideas for using songs in the English language classroom”. English Teaching Forum, 34(1), 46-47.

[13] Griffee, D. T. (1990). "Hey baby! Teaching short and slow songs in the ESL classroom”. TESL Reporter, 23(4), 3-8.

[14] Griffee, D. T. (1992). Songs in Action (pp. 324-328). Hertfordshire: Prentice Hall International.

[15] Hammond, E.R. (1989). Critical Thinking, Thoughtful Writing. USA: McGraw-Hill

[16] Harris, J. (1993). Introducing Writing (pp. 23-26). London: Penguin.

[17] Hedge, T. (2000). Teaching and learning in the language classroom (pp.90-95). Oxford: Oxford University Press.

[18] Krashen, S. D. (1981). Second language acquisition and second language learning (pp.342-346) Oxford: Pergamon Press.
[19] Krashen, Stephen D. (1987). Writing, research, theory and applications. Oxford: Pergamon Press.

[20] Lozano, G., (1979). Suggestology and outlines of suggestopedy(pp.34-36). New York: Gordon and Breach Science Publishers.

[21] Littlewood, W. (1995). Writing and Reading as a Joint Journey through Ideas. Anthology Series 12(35), 421-434. Singapore: RELC.

[22] Lo, R. \& Li, H.C. (1998). "Songs enhance learner involvement”. English Teaching Forum. 36(7), 8-11.

[23] McCarthy, W. (1985). "Promoting language development through music". Academic Therapy, 21(2), 237-242.

[24] Murphey, T. (1992). Music and Song. Oxford: Oxford University Press.

[25] Ostrander, S. \& Schroender, L. (1979). Superlearning (pp.432-439). New York: Dell Publishing Company

[26] Oxford, R. L. (1999). "Anxiety and the language learner: new insights”. In Jane Arnold (Ed.), Affect in Language Learning (pp.16-22).Cambridge University Press.

[27] Sasaki, Miyuki (1990). "Development of an analytic rating scale for Japanese L1 writing”. Language Testing, 16(4), 457-478.

[28] Walker, J. T. (1996). The psychology of learning. New Jersey: Prentice Hall. Retrieved Nov. 2003 from http://wvwv.essortment.com/musiceffectbra_rqxt.htm 